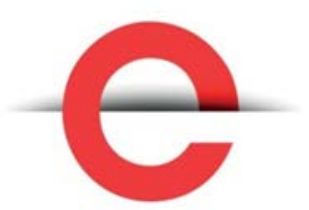

U T S

e P R E S S
Cosmopolitan

Civil Societies: an

Interdisciplinary

Journal

Vol. 9, No. 3

2017

C 2017 Olga Oleinikova.

This is an Open Access

article distributed under the

terms of the Creative

Commons Attribution 4.0

Unported (CCBY 4.0)

License (https://

creativecommons.org/

licenses/by/4.0/), allowing

third parties to copy and

redistribute the material in

any medium or format and to

remix, transform, and build

upon the material for any

purpose, even commercially, provided the original work is properly cited and states its license.

Citation: Oleinikova, O. 2017. Foreign Funded NGOs in Russia, Belarus and Ukraine: Recent Restrictions and Implications. Cosmopolitan Civil Societies: an Interdisciplinary Journal. 9(3), 85-94.

http://dx.doi.org/10.5130/ccs.v9 i3.5637

ISSN 1837-5391 | Published by UTS ePRESS |

$\underline{\text { mcs.epress.lib.uts.edu.au }}$
REFEREED PAPER

\section{Foreign Funded NGOs in Russia, Belarus and Ukraine: Recent Restrictions and Implications}

\section{Olga Oleinikova}

University of Technology Sydney, Australia

Corresponding author: Olga Oleinikova, School of Communication, Faculty of Arts and Social Sciences, University of Technology Sydney, 15 Broadway, Ultimo, NSW 2007, Australia. Olga.Oleinikova@uts.edu.au

DOI: http://dx.doi.org/10.5130/ccs.v9i3.5637

\section{Abstract}

The opportunity for public participation through NGO action in post-communist societies is continuously starved by legal framework. Since the collapse of the Soviet Union, NGOs in Russia, Ukraine, Belarus and other post-Communist states have traditionally looked abroad for their funding, and are dismayed at recent legislation setting up new barriers to this practice. This paper discusses the new laws and restrictive amendments to legislative acts on the operations of foreign funded NGOs in Russia, Belarus and Ukraine, adopted since 2011.

\section{Keywords}

NGOs; Foreign funding; Regulations; Russia; Belarus; Ukraine
DECLARATION OF CONFLICTING INTEREST The author declared no potential conflicts of interest with respect to the research, authorship, and/or publication of this article. FUNDING No funding was provided for the writing of this paper. 


\section{Introduction}

The opportunity for public participation through NGO action in post-communist Eastern European societies is continuously starved by legal frameworks. Since the collapse of Soviet Union, NGOs in Russia, Ukraine, Belarus and other post-communist states have traditionally relied on financial support from abroad - mostly from the United States and British government bodies - all working on various aspects of institutional development, such as helping to promote human rights, freedom of the press and independent media, and establishing pro-democracy groups, as well as trying to activate citizens' participation in post-Soviet space. Today the situation has changed slightly. The majority of foreign funded NGOs in Ukraine, Belarus and Russia receive their financial support from the private sector and individual donors - private Western donors, the National Endowment for Democracy (NED) and Open Society Foundations. In the last five years with the change in the foreign donorship landscape and continuous turbulence of democratization processes in postcommunist states, Russian, Belarusian and Ukrainian governments have adopted new sets of legislation and amendments to laws on the operations of foreign funded NGOs.

The scholarly mainstream democracy and civil society literature (Zielonka \& Pravda 2001; Mendelson \& Glenn 2012; Carmin 2010; Wedel 2015; Dimitrova \& Pridham 2004) contains very little about foreign funded NGOs and limitations to their operations in postSoviet Eastern Europe, like that set of new laws and amendments recently adopted in Ukraine, Belarus and Russia. This paper fills that void by describing the new laws and restrictive legislative acts adopted since 2011 in Russia, Belarus and Ukraine and discusses the effects such laws have on the operations of the NGO sector and broader democratization processes in these three post-communist countries.

Through a comparative perspective, this paper argues that the recent restrictive legislation creates new barriers to NGOs' operations and relationships with foreign partners (e.g. in Russia and Belarus) and damages the potential for NGOs to organize mutual aid and provide support for democratic efforts to a young unstable democracy (e.g. Ukraine). Furthermore, this new legislation is argued to affect the marketization of the NGO sector in Ukraine, Belarus and Russia, pushing NGOs to adopt the approaches and values of the private market, which risks harming the fragile democracy and fails to create and maintain a strong civil society. The strong civil society, understood as NGOs, think tanks, movements and civil actions, is one of the key elements of democracy (Keane, 2013). Pospieszna (2014), and McFaul (2010) argue that in the process of undermining authoritarian communist regimes in Eastern Europe, civil society and its actors, such as NGOs, play an important role. Thus developing civil society and supporting NGOs is likely to assist those Eastern European nations struggling for democracy. In this way, the crucial relationship between civil society and democratization, as well as aiding foreign donors' focus on civil society as they assist in the struggle for democracy, makes civil society and NGOs a critical component of postcommunist transformations in Russia, Ukraine and Belarus.

To develop and support this argument, the paper first explores Russia's 'Foreign Agents' law on NGOs adopted in 2012 and the implications of this law in Russia. Secondly, 
it investigates the circulation of foreign funds in Belarus and the new laws adopted in 2013. Thirdly, the paper discusses the most recent Ukrainian law on NGOs that signposts a rollback of anti-corruption efforts and may slow down the democratic development in Ukraine. Finally, the paper draws a comparison between these three cases and summarizes the risks such new laws and restrictions may have for further operations of NGO sector and democratization of the post-communist states.

\section{Russia’s 'Foreign Agents' law on NGOs}

The 'Foreign agent' law, officially titled 'On Amendments to Legislative Acts of the Russian Federation regarding the Regulation of the Activities of Non-profit Organisations Performing the Functions of a Foreign Agent' [Федеральный закон 121 "Об иностранных агентах"], is a law that was adopted in 2012 in Russia that demands those NGOs that receive foreign funding and engage in vaguely defined 'political activity' to register and declare themselves as 'foreign agents'. Such NGOs must be listed on the 'foreign agents' register, which is administered by the Ministry of Justice. The term 'foreign agent' covers a very wide range of meanings. In a number of post-Soviet Eastern European countries the term 'foreign agents' is used to identify individuals or organizations engaged in domestic political activity on behalf of a foreign state and their activities are subject to restrictions. Due to the fact that foreign agents are also called 'spies' and 'traitors', the phrase 'foreign agent' in the Russian language has a negative connotation and strong associations with cold war-era propaganda and espionage. The 'foreign agent' law has been widely criticized both in Russia and internationally as a violation of democratic ethics, human rights and as being designed to chilling civil society and counter opposition groups that receive funding from the West.

Russia's NGOs faced difficult times and protested against the law calling it 'unjust' and 'slanderous', arguing for free engagement and vital debate between Russia's citizens and those in power to ensure Russia's international human rights obligations and commitments. Vladimir Lukin, Russia's then-federal ombudsman, has challenged this law in 2013 in the Russian Constitutional Court. However, in 2014 the court supported and retained the law with no further amendments having found no legal or constitutional grounds for the use of the term 'foreign agents' in a negative sense and finding no intention 'to persecute or discredit' foreign funded NGO organizations (Human Rights Watch, 2017). The court also recognised that the 'foreign agent' label was 'in line with the public interest and the interest of state sovereignty’ (Human Rights Watch, 2017).

This law has impacted foreign funded NGOs in Russia in several ways. NGO's had two choices: (1) to continue accepting funding from overseas and being labelled as 'foreign agent' or (2) discontinue partnership with foreign funders and donors and rely on domestic funding and presidential grants. The 'foreign agents' law has made the receipt of foreign funding a high-risk activity. The government has indicated that NGOs can use overseas funding, but it will cost them their good reputation and bring potential legal risks. Some human rights activists argue 'it was the plan from the very beginning - to cut off foreign funding and then give domestic funding only to loyal organizations' (Amnesty International, 2016). Cutting off overseas funding and making Russian NGOs reliant on domestic funding 
might make NGOs in Russia less free and more prone to self-censorship in order to guarantee their operations and continued funding from the state. Basically, the main source of NGOs operations and survival in Russia - foreign funding - has turned into an insecure source that automatically puts those organisations that engage in what is deemed to be political activity in a position where they have to face legal consequences for failure to comply.

As of 11 October 2016, there were 226,995 NGOs in Russia and by 24 October 2016, according to a report by Human Rights Watch, the list of active 'foreign agents' included 105 NGOs. Of those, 'four registered as 'foreign agents' voluntarily and at least 58 were prosecuted for not doing so’ (Human Rights Watch, 2017). The offices of numerous NGOs, including well-regarded international NGOs the likes of Transparency International, Amnesty International and Human Rights Watch, were targeted by Russian law enforcement officers to confiscate documents and records related to their activity. Amnesty International says that 'Russia's controversial 'foreign agents' law is an assault on freedom of expression' (Amnesty International, 2016) that caused numerous NGOs to restrict their operations with more than 27 closed down. These NGOs have played a significant and necessary role in defending the rights of ordinary people and ensuring their needs are addressed. These NGOs delivered services that the state has failed to provide, such as 'legal representation or psychological support for victims of discrimination or violence and environmental monitoring' (Amnesty International UK, 2016).

\section{Belarusian restrictions on foreign funding}

Circulation of foreign funds in post-Communist countries was always difficult, especially in Belarus. However, before 1999 there were no limitations on foreign grants and support; Western partners could freely cooperate with Belarusian organisations on any projects and fund them. NGOs in Belarus 'have always been not the most beloved actors for the regime' (Chulitskaya \& Chavusau, 2013, p. 1). Human rights focused NGOs have been targeted by restrictive laws in an attempt to constrain their capacity to drive accountability advocacy (Matonytė \& Chulitskaya, 2012). Registration difficulties, various restraints, 'persecution and even imprisonment are always one step behind the organizations that are not loyal to the Belarusian government' (Matonyte \& Chulitskaya, 2012). After the adoption of a set of restrictive legislative amendments to a number of Belarusian legislative acts in 2011, the operation of Belarusian civil society groups, especially human rights NGOs, has become 'severely restricted by a number of limitations on freedom of assembly and association' (Civil Rights Defenders, 2011).

Since 3 October 2011 the operation of NGOs in Belarus has been officially limited by a set of restrictive legislative amendments to a number of Belarusian legislative acts adopted by the lower house of Belarusian Parliament. Particular limitations scrutinised the operations of foreign funded NGOs. Among the key restrictions that came into effect in October 2011 are 'mandatory registration of donor aid in state institutions with criminal liability introduced in autumn 2011 for violating rules of receiving foreign aid, along with tightening previous administrative sanctions' (Chulitskaya \& Chavusau, 2013, p. 4). NGOs are also restricted from holding accounts in foreign banks. All the money transferred from abroad has to be 
approved by Belarusian government; so foreign NGOs and sponsors cannot transfer money directly into the Belarusian bank accounts of their Belarusian partner NGOs (Pospieszna, 2014). Many foreign organisations found it impossible to track their money because the political situation forces them to transfer funds to the bank accounts of private individuals or to deliver funding in cash.

The international community has reacted to the new law with grave concerns and anxiety about the proposed legislative changes for the operations and funding of Belarusian NGOs. Article 21 'prohibits Belarusian NGOs from keeping funds in banks and other financial institutions on the territory of foreign states' (Human Rights Watch, 2011). Importantly, administrative penalties can be applied to those NGOs that accept financial support from overseas 'in violation of law'. In a similar manner, the Criminal Code of Belarus, as amended, establishes 'criminal liability for receiving any foreign grants or donations in violation of the Belarusian legislation' (Human Rights Watch, 2011). The international community has signaled that such regulations may result in indiscriminate persecution of any activist or civil society group that receives overseas funding. For years, Belarusian civil society groups have been 'forced by the government to operate in increasingly difficult conditions and struggle with arbitrary registration procedures' (Chulitskaya \& Chavusau, 2013, p. 3). By creating further restrictions in relation to receiving funding from abroad, the new legislation inevitably pushed civil society groups to the margins of the law and made their operation in Belarus close to impossible. Furthermore, receiving foreign funding subject to the authorization procedures of the state authorities 'made it virtually impossible for many to obtain support legally (e.g., for the Belarusian Helsinki Committee)' (Matonyte \& Chulitskaya, 2012, p. 237). Interestingly, as Matonytė \& Chulitskaya (2012) has pointed out, anonymous donations 'were made equal by the law to foreign ones and are subject to the same rigid authorization procedure'. Along with the above mentioned, criminal liability has been ratified for violating rules of receiving foreign donations (e.g., using foreign donations without registration). The only legal source of funds for NGOs in Belarus, uncontrolled by the state, is donations from individuals.

Article 356 of the Criminal Code suggests a 'new expanded definition of 'espionage', which will include 'intelligence gathering activity' or 'any form of other assistance to a foreign state, foreign organization or their representative in carrying out activities to the detriment of the national security of Belarus' (Human Rights Watch, 2011). This broad definition was argued by international community to be potentially used for targeted persecution by the authorities of NGO activists and civil society leaders.

Additionally, international NGOs expressed serious concerns about the amendments to the Law on State Security Agencies, which allowed for substantial extension of the powers of the State Security Committee (KGB). Consequently, the new law had serious consequences for foreign funded NGOs in Belarus. As a result, 'the necessity to show their loyalty to the government in order to be able to function made Belarus less NON-governmental' (Chulitskaya \& Chavusau, 2013, p. 4). 


\section{Ukraine's new law on NGOs: a roll-back of anti-corruption efforts}

Despite the fact that Ukraine has progressed further in its democratic development than Belarus and Russia with no restrictions around overseas funded NGOs, some of the new laws give warning signs of a roll-back of the recent democratic reforms and anti-corruption efforts of pro-democracy groups and NGOs in Ukraine. In early 2014 there was an attempt to introduce in Ukraine a law similar to Russia's 'Foreign Agents' law that failed by not getting any government and public support. However, the most recent controversial legislation around anti-corruption NGOs has been passed in Ukraine giving a signs of democratic rollback.

On 27 March 2017, a strong majority in Ukraine’s parliament (266 of 423 legislators) passed the controversial legislation, and President Petro Poroshenko signed a series of amendments to Ukraine's Law on the Prevention of Corruption. These revisions require members of Ukraine's anti-corruption NGOs to release their financial e-declarations. According to the law, every person who received funds or property within the international framework of delivering programs (projects) or technical assistance in Ukraine, including permanent assistance in the field of anti-corruption policy and implementation of such policies (directly or through third parties) is required to submit financial declaration.

Such a requirement immediately elicited a response from civil society groups and the investigative journalist community. This controversial legislation provoked 'a considerable backlash by political proponents of the amendments, as well as some segments of society who felt that the amendments would promote more transparency amongst NGOs involved in combatting corruption' (OpenDemocracy, 2017).

Following the Maidan mass protests in 2013-2014, Ukraine’s political leadership pledged ambitious anti-corruption reforms to create a more transparent government to achieve a stronger democratic state. One of the key reforms has required Ukraine's state officials to publicly declare their assets annually through an online filing system. Anticorruption legislative reforms were among the conditions the Ukrainian government agreed to fulfill to meet requirements for visa-free travel by Ukrainians to the European Union' (Human Rights Watch, 2017).

Several opponents of the amendments immediately condemned the new legislation. José Ugaz, chairman of Transparency International, proclaimed that: 'These amendments are a vindictive retaliation by lawmakers who are angry that they are required to declare their wealth. There is no justification for singling out anti-corruption groups.' Transparency International in Ukraine has made an official call on Ukrainian authorities to abolish controversial amendments to the Law on Prevention of Corruption that appears designed to intimidate and target anti-corruption activists. Transparency International has pointed out that 'the initial law was introduced to inhibit corruption and allow for public scrutiny of the wealth of those in power to ensure people did not abuse their official positions to increase their assets beyond their salaries' (Transparency International, 2017). It was emphasised that the law has no relevance to anti-corruption NGOs and activists who are not paid by the state. 'This new requirement is a slap in the face for Ukraine's anti-corruption activists and its 
international partners who have been calling for a more transparent government', said Tanya Cooper at Human Rights Watch.

Key to understanding this restrictive new reality for NGOs and activists in Ukraine is a series of clauses that amend Ukraine's Law on the Prevention of Corruption. The amendments 'target individuals and representatives of 'anti-corruption' organisations that are involved in any activities, which are related to the prevention of corruption' (OpenDemocracy, 2017). Experts and lawyers have argued that the wording in the amendments is too vague and this makes it very difficult to predict which particular organization will fall under declaration. Perhaps this will be limited only to Transparency International, the Centre for Combating Corruption, the Anti-Corruption Headquarters, and so on, whose statutory documents accurately state that they are engaged in the fight against corruption. Or maybe the Bureau of Journalistic Investigations will also fall under this law along with the NGO 'Our Money' which carry out journalistic investigations but de facto conduct activities to fight corruption. The absence of a precise definition (or any definition at all) of 'what 'anti-corruption activities' entails, or which individuals or entities are subject to this law, drew the ire of both NGOs and donors alike' (OpenDemocracy, 2017).

The above mentioned concerns come from the grey areas this law leaves for the authorities to use vague definitions to prosecute civil society activists according to the subjective explanation of the law. The main argumentation against the new law is that it obscures the main idea of establishing financial declarations of public servants' incomes and assets - namely, 'to enable the Ukrainian public, journalists and civil society to hold officials accountable’ (OpenDemocracy, 2017).

\section{Conclusion}

As democratization has travelled East and passed through regime change in the post-Soviet states of Eastern Europe, it seems to become more obviously intertwined with external international actors and their involvement in the NGO sector. A key point of the analysis given above is the discovery that the dynamics in the NGO sector in Russia, Belarus and Ukraine have experienced some stagnation since 2011, when the new restrictive legislations on foreign funding and operations of NGOs was adopted by the governments of these three post-communist states. This new legislation has created a significant domestic counter 'push' against the international Western 'pull' towards democracy.

The situation with foreign NGO funding in Russia and Belarus is much different from Ukraine, with strict laws on 'foreign agents' and harsh regulations on foreign money transfers and aid. Any restrictions on foreign funded NGOs and such laws as the 'foreign agents' law have been recognised by international community as having a damaging effect on individual rights, the quality of civic discussion and pluralism of opinions and social and political groups. Such a push away from Western financial support in Russia and Belarus is reminiscent of the flight away from the Western 'subordination', typically seen in these two countries as undermining their national sovereignty. This new legislation has impacted the efforts of civil society groups and NGOs to democratize post-communist social, economic and political spheres in Russia and Belarus in the following ways: 
- NGOs had to discontinue partnership with foreign funders and donors and search for other sponsorship opportunities and presidential grants inside the countries. Such dynamics have diminished the pluralism of civic initiatives and various interest groups, caused marketization of the NGO sector to serve the interests of particular interest groups and fight counter opposition.

- The underfunded condition has caused a cooling in the civil society and opposition movements and groups that received funding from the West.

- A significant number of the foreign funded NGOs had to discontinue their work, which had immediate effects on pluralism, diversity and the general progression towards a democratic vector of development.

The situation in Ukraine is different from that in Russia and Belarus. Foreign funded NGOs, foreign investments and pro-democracy groups have long been pillars in Ukraine's civic society, facilitating the dissemination of the nation's wealth fairly and justly during the past 27 years (Sornarajah, 2017). The recent legislation adopted in 2016 in Ukraine does not imply any restrictions on the acceptance of foreign funding by NGOs and the civic sector in Ukraine, though it imposes some regulation on their operations and enforces the framework of preventative measures to ensure transparency and accountability of civic activists and groups in the country. This new law has received considerable criticism for having too many grey areas, but if it the case that a more strict financial declarations and transparency from civic groups and activists are something the Ukrainian public truly wants and feels the need for its accountability, 'then a reasonable and practical legal framework should be developed' (OpenDemocracy, 2017). It is too early to conclude that there are signs of a democratic rollback in Ukraine's civil society sector. However, the recent restrictive legislation has created a significant amount of new barriers to NGOs' operations and relationship with foreign partners in Russia and Belarus and in Ukraine, it has the potential to damage the possibilities for NGOs to organize mutual aid and support the development of the young unstable democracy.

\section{References}

Amnesty International (November 17, 2016), 'Agents of the people: Four years of foreign agents law in Russia’: https://www.amnestyusa.org/reports/agents-of-the-people-fouryears-of-foreign-agents-law-in-russia/

Amnesty International UK (November 18, 2016), 'Russia: four years of Putin's foreign agents law has 'shackled and silenced' NGOs - new report': https://www.amnesty.org.uk/pressreleases/russia-four-years-putins-foreign-agents-law-has-shackled-and-silenced-ngosnew-report

Carmin, J. 2010, 'NGO capacity and environmental governance in Central and Eastern Europe', Acta Politica, vol.45, nos.1-2, pp. 183-202. https://doi.org/10.1057/ap.2009.21. 
Chulitskaya, T. \& Chavusau Y. 2013, 'Belarusian NGOs: Between Belarus and abroad', Bell; BelarusInfo Letter, issue 4 (34), pp. 1-6.

Civil Rights Defenders (October 20, 2011),'Law amendments a threat to civil society', https://www.civilrightsdefenders.org/news/statements/law-amendments-a-threat-tocivil-society/

Crotty, J. 2009, 'Making a difference? NGOs and civil society development in Russia', Europe-Asia Studies, vol.61, no.1, pp. 85-108. https://doi.org/10.1080/09668130802532936.

Dimitrova, A., \& Pridham, G. 2004, 'International actors and democracy promotion in Central and Eastern Europe: The integration model and its limits', Democratization, vol.11, no.5, pp. 91-112. https://doi.org/10.1080/13510340412331304606.

Human Rights Watch (July 4, 2017), 'Russia: Government vs. Rights Groups', https://www.hrw.org/russia-government-against-rights-groups-battle-chronicle

Human Rights Watch (April 5, 2017), 'Ukraine: New Law targets anti-corruption activists, journalists', https://www.hrw.org/news/2017/04/05/ukraine-new-law-targets-anticorruption-activists-journalists

Human Rights Watch (October 20, 2011), 'Belarus: Open joint NGO letter to the Parliament of Belarus’, https://www.hrw.org/news/2011/10/20/belarus-open-joint-ngo-letterparliament-belarus

Keane, J. 2013. 'The dawn of monitory democracy’, in Tragårdh, L., Witoszek, N., \& Taylor, B. (eds.), Civil Society in the Age of monitory democracy, Berghahn Books, Oxford, chapter 1.

Kryvoi, Y. 2016, Belarus: Nations in Transition 2016, Available at: https://freedomhouse.org/report/nations-transit/2016/belarus

Matonyte, I., \& Chulitskaya, T. 2012, 'The third sector and political communication in Belarus: Highlights on the topic of social policies from the presidential campaign 2010’, Lithuanian Annual Strategic Review, vol.10, no.1, pp. 235-263.

McFaul, M. 2010, 'The missing variable: The "International System" as the link between third and fourth wave models of democracy', in Bunce, V., McFaul, M. \& StonerWeiss, K. (eds.), Democracy and authoritarianism in the post-communist world, Cambridge University Press, Cambridge, pp. 3-29.

Mendelson, S. E., \& Glenn, J. K. (eds.), 2012, The Power and Limits of NGOs: A Critical Look at Building Democracy in Eastern Europe and Eurasia, Columbia University Press, New York.

OpenDemocracy (April 10, 2017), 'A controversial law takes aim at Ukraine’s anticorruption NGOs’, https://www.opendemocracy.net/od-russia/devinackles/controversial-law-takes-aim-at-ukraine-s-anti-corruption-ngos

Pospieszna, P. 2014, Democracy assistance from the third wave: Polish engagement in Belarus and Ukraine, University of Pittsburgh Press, Pittsburgh, PA. https://doi.org/10.2307/j.ctt7zw8d3.

Sornarajah, M. 2017. The International Law on Foreign Investment, $4^{\text {th }}$ ed. Cambridge University Press, Cambridge. 
Stewart, S. 2009, 'NGO development in Ukraine since the Orange Revolution', in BestersDilger, J. (ed.) Ukraine on its Way to Europe, Interim Results of the Orange Revolution/ed. Peter Lang, Frankfurt Am Main, pp. 177-194.

Spiegel (March 26, 2013), 'NGO Law Monitor: Russia', http://www.spiegel.de/international/europe/russian-authorities-raid-germanfoundations-and-ngos-a-890969.html

Transparency International 2017, 'Proposed Amendments to a law that targets Ukrainian anticorruption groups must be abolished', https://www.transparency.org/news/pressrelease/proposed_amendments_to_a_law_that _targets_ukrainian_anti_corruption_groups

Wedel, J. R. 2001, Collision and collusion: The strange case of Western aid to Eastern Europe. St. Martin's Press.

Zielonka, J., \& Pravda, A. (eds.), 2001, Democratic Consolidation in Eastern Europe: Volume 2: International and Transnational Factors, Oxford University Press, Oxford. https://doi.org/10.1093/019924409x.001.0001 